\title{
Gender Differences Among Academic Staff and Students Offering STEM in National Universities in Uganda: The Case of Kyambogo University
}

\author{
Harriet Kebirungi ${ }^{1}$, Fabian Nabugoomu ${ }^{2}$, Jackson-Gilbert Mwanjalolo, Majaliwa ${ }^{3}$ \\ 1.Harriet Kebirungi, Department of Development Studies, Kyambogo University, P.O. Box 1, Kampala, Uganda \\ 2.Fabian Nabugoomu, Vice Chancellors' Office, Kyambogo University, P.O. Box 1, Kampala, Uganda \\ 3.Jackson-Gilbert Mwanjalolo Majaliwa, Department of Geography, Geoinformatics, and Climatic Sciences \\ Makerere University P.O. Box 7062 Kampala, Uganda
}

\begin{abstract}
Female University students and academic staff continue to be underrepresented in Science, Technology, Engineering, and Mathematics (STEM) fields. This study examined the status of female academic staff and students offering STEM at Kyambogo University (KyU), Uganda. The status and trend of female to male ratio of academic staff and students were determined. Practical strategies and policies for narrowing the gender gap for students offering STEM were identified. The status and trend of female to male ratio of students was determined by analyzing Student's Academic Registrar's and graduation records for the academic year 2014-2018. For academic staff, a gender analysis of Human Resources records was conducted based on the number of male or female academic staff teaching at the University in both STEM and non-STEM disciplines. There was an increase over time in student's graduation from the Non-STEM fields with $\mathrm{R}^{2}=0.3254$ for the undergraduate programmes $(\mathrm{P}<0.05)$. The number of students in STEM fields declined gradually overtime, $\left.\mathrm{R}^{2}=0.91 ; \mathrm{P}<0.05\right)$. Male dominance among students and leadership position among academic staff in STEM and Non-STEM fields was evident. Difference between career pathways are causes for low female students and academic staff enrolment and teaching in STEM fields. The University needs to implement gender responsive programmes that enhance entry, retention, and participation in leadership positions for both female staff and students in STEM fields.
\end{abstract}

Keywords: Status, Female Academic Staff and Students, STEM, Kyambogo University

DOI: $10.7176 / \mathrm{JEP} / 12-24-09$

Publication date:August $31^{\text {st }} 2021$

\section{Background}

Majority African societies are patriarchal with several restrictions on strategic interventions for transforming society (Tamale 2008). African patriarchal systems socially stratify and differentiate societies based on sex and societal roles in favor of males while constraining the roles and activities of females (Aina 1998). Contributing factors to this scenario is that women's situations are universal, and globally women face a lack of access to, and control over resources and decision making (Parpart et al. 1989). This situation has kept the number of educated females across the continent very low (Lone et al. 2019).

However, overtime women's numbers started increasing as the society started to realize that men and women are wheels of carriage towards sustainable development (Crittenden et al. 2019). For example, the postindependence period has seen a tremendous increment in the number of educated women on the continent and has presented more meaningful opportunities for women in the continent to demand equality of access to citizenship rights, resources, and representation (Pailey 2019). This has opened opportunities for women and some are serving as teachers, Doctors, Engineers, Administrators, and even Head of the State. However, in Uganda, the general picture at the national level still shows male dominance in Public Service leadership positions at all levels of education as shown in Table 1 below. In addition, the ratio of female to male ratio declines as you move up in different education levels except for pre-primary education where there is a high concentration where there is a feminized teaching profession as presented in table 2 below. The observed trend is probably an indication that less females are enrolled to occupy leadership positions.

Table 1: Size of Public Service by Sex and Positions Held

\begin{tabular}{|l|l|l|l|l|}
\hline Salary Scale & Total Employees & \%of Male & \%of Female & Female to male ratio \\
\hline Senior Management (U1) & 800 & 78 & 22 & 0.28 \\
\hline Middle Management ((U2-U3) & 4,180 & 84 & 16 & 0.19 \\
\hline Graduate \& Diploma Entry (U4-U5) & 59,978 & 72 & 28 & 0.39 \\
\hline Lower level (U6-U8) & 206,893 & 65 & 35 & 0.54 \\
\hline Total & $\mathbf{2 7 1 , 8 5 4}$ & $\mathbf{6 7}$ & $\mathbf{3 3}$ & 0.49 \\
\hline
\end{tabular}

Source: Ministry of Public Service Payroll Monitoring Unit as Extracted from Circular No. 2 of 2011. 
Table2: Teachers, Lecturers and Instructors by level

\begin{tabular}{|l|l|l|l|}
\hline Level & Female & Male & Female to male ratio \\
\hline University and colleges (Full time) & 397 & 1,341 & 0.23 \\
\hline Tertiary Level (Excluding University) & 1,990 & 4,779 & 0.29 \\
\hline Secondary (Only Government) & 6,554 & 19,416 & 0.25 \\
\hline Primary (Government) & 50,134 & 76,314 & 0.40 \\
\hline Primary (Private) & 20,390 & 25,565 & 0.44 \\
\hline Pre-Primary & 16,500 & 3.344 & 0.83 \\
\hline Total & $\mathbf{9 5 , 9 6 5}$ & $\mathbf{1 3 0 , 7 5 9}$ & $\mathbf{0 . 4 2}$ \\
\hline
\end{tabular}

Source: Uganda Education Statistical Abstract, 2010

Although it is important to ensure that there are sufficient numbers of qualified women entering the public service, attention needs to be paid to ensuring that able women can progress to senior positions. However, even in professions that are apparently feminized such as education, a pyramid with men in the top positions still exists. It is very likely that the continued low levels of women in the education systems also affect their involvement in Public Service. Female involvement in Public Service is higher in the lower levels of public service, but still their number is half that of male counterparts.

These aforementioned figures in Tables I and 2 prompted us to make an enquiry on the status of women in education in the country with a focus on academic staff and student's in science, technology, engineering and mathematics (STEM). STEM fields in this article include mathematics, sciences (including physical sciences, chemistry, and biological sciences), engineering/engineering technology, and computer/information sciences (Chen,2009). The enquiry is based on the country and the importance it attaches to STEM disciplines to harness the current and future economic and social well-being. Currently, $75 \%$ of the fastest growing global occupations require STEM skills and knowledge (McLaughlin 2017). Although globally the gender gap in STEM enrollment and performance has narrowed, female university students and academic staff continue to be underrepresented in STEM fields (Chen 2009). Students Who Study Science, Technology, Engineering, and Mathematics (STEM) in Postsecondary Education. Stats in Brief. NCES 2009-161. National Center for Education Statistics. (Wang \& Segol 2017). Continuous limitations for females studying and operating in maledominated STEM programmes persists (Tacsir et al. 2014); (Hernandez 2016); (Hutton \& Dixon 2016); (Jackson 2016).

In Uganda, STEM disciplines are influenced by poverty, disability, post-conflict history, and accessibility to educational institutions (Government of Uganda 2011). This signifies low female's entrepreneur and innovation skills and competencies, which attracts limited recognition of technical skills among university female students and academic staff. This situation widens the gender gap among university academic female staff and student's enrollment and participation in STEM. Other fields that are affected are the legislative bodies that are left in limbo for policy advocacy on topical debates such as education, health, economic, and political at institutional, national, and international levels (Hutton \& Dixon 2016); (Swers 2013).

Gender differences in career pathways and choices, gender roles, expectations, and openings, especially for women, get in the way to determine their entrance and perseverance in STEM professions (Grubbs \& Grubbs 2016). Issues of gendered patterns of participation in post - compulsory STEM education, limited recruitment opportunities in physics and engineering have remained closed entries for women (Smith 2010). Others include retention, campus culture, classroom experiences, and identity (Blackburn 2017). Lack of role models (peers, teaching assistants, and instructors) and the very nature of science (Herrmann 2016) and limited genderresponsive reforms in science education donate to the removal of women from the STEM field ( Blickenstaff 2006).

The Government of the Republic of Uganda is increasing access to education in primary, secondary, and universities country wide. However, there were no commensurate teachers or lecturers of mathematics, Physics, Chemistry, and Biology combinations (Government of Uganda 2011). Hard to reach schools and the lack of required social and technical school amenities made it even difficult for STEM teachers to teach in those locations (Government of Uganda 2011). On the other hand, women in STEM can interest future generations of girls and women in STEM fields, because the presence of similar models fosters entry into and persistence in STEM professions (Riegle-crumb \& Moore 2014; Young et al. 2013).

Literature on women in STEM fields exists on mental ability, relative cognitive, occupational interests or preferences, lifestyle values or work-family balance preferences, field-specific ability beliefs, and genderrelated stereotypes and biases (Young et al. 2013). Most of these studies, however, have been conducted outside Africa. Furthermore, these studies have not clearly raised the profile and importance of STEM female students and academic staff in universities. This study therefore I) determined the status and trend of female to male ratio of academic staff and students, and ii) identified any practical strategies and policies for narrowing the gender gap for students offering STEM at KyU. 


\section{Methodology}

This study was conducted at Kyambogo University (KyU), Kampala in Uganda. KyU is one of the upgraded technical college to public Universities. The choice of the University of the study was to represent the old and new universities and was also based on availability and access to the required data. It has a student population of 24, 053 (12,763 males and 11, 529 females). The University is hosted under 6 faculties and 1 school of which three are STEM (Vocational Studies, and Faculties of Science and Engineering). Information used for this study was obtained from Academic Registrar's records (admissions, registration and retention, and graduation) for the academic year 2014-2018. The status and trend of female to male ratio of students was determined by analyzing the admissions and registration records; and by determining their change over time using regression techniques. For academic staff, a gender analysis of Human Resources records was conducted. The review and analysis were generally based on the number of male or female academic staff teaching at the University in various academic fields including those of STEM. Permission to conduct this study was granted by the Vice Chancellor of Kyambogo University.

\section{Findings}

\subsubsection{Status of female to male ratio of academic staff in STEM and Non-STEM Departments}

Generally, the number of female academic staff in STEM and Non-STEM departments tended to be lower than the male academic staff, departmental faculty staff in STEM were 90 females compared 154 males, 154 in nonSTEM departments; and females (59) compared to males (111) in STEM departments. However, there was no association between discipline (STEM and Non-STEM) and gender of the staff (Chi-square $=\mathrm{df}=1, \mathrm{p}>0.05)$. In other words, at the level of the University, there was a similar female and male ratio in STEM and Non-STEM disciplines, which was almost half the number of male staff.

Males tended to dominate the physical sciences (chemistry, physics, engineering, and technology). However, within STEM, the ratio of female to male staff was highest in the departments of biological science and human nutrition and home economics. The female to male ratio for human nutrition and Home Economics was of 2 compared to less than half for Civil Engineering. The female to male ratio was lowest in the departments of Civil Engineering followed by Economic and Statistics, Land and Architectural Studies, and Mathematics. The dominance of female staff in biological science and human nutrition and home economics is perhaps attributed to their feminine roles ascribed by society.

\subsubsection{Admission of female to male ratio at Kyambogo University}

The admission of female to male ratio in 2012 was 0.84 . It has significantly declined linearly by 0.011 per year up to 2016. In the absence of any intervention, then we expect a further decline of female student's admission in the years to come as indicated in Figure 1 below.

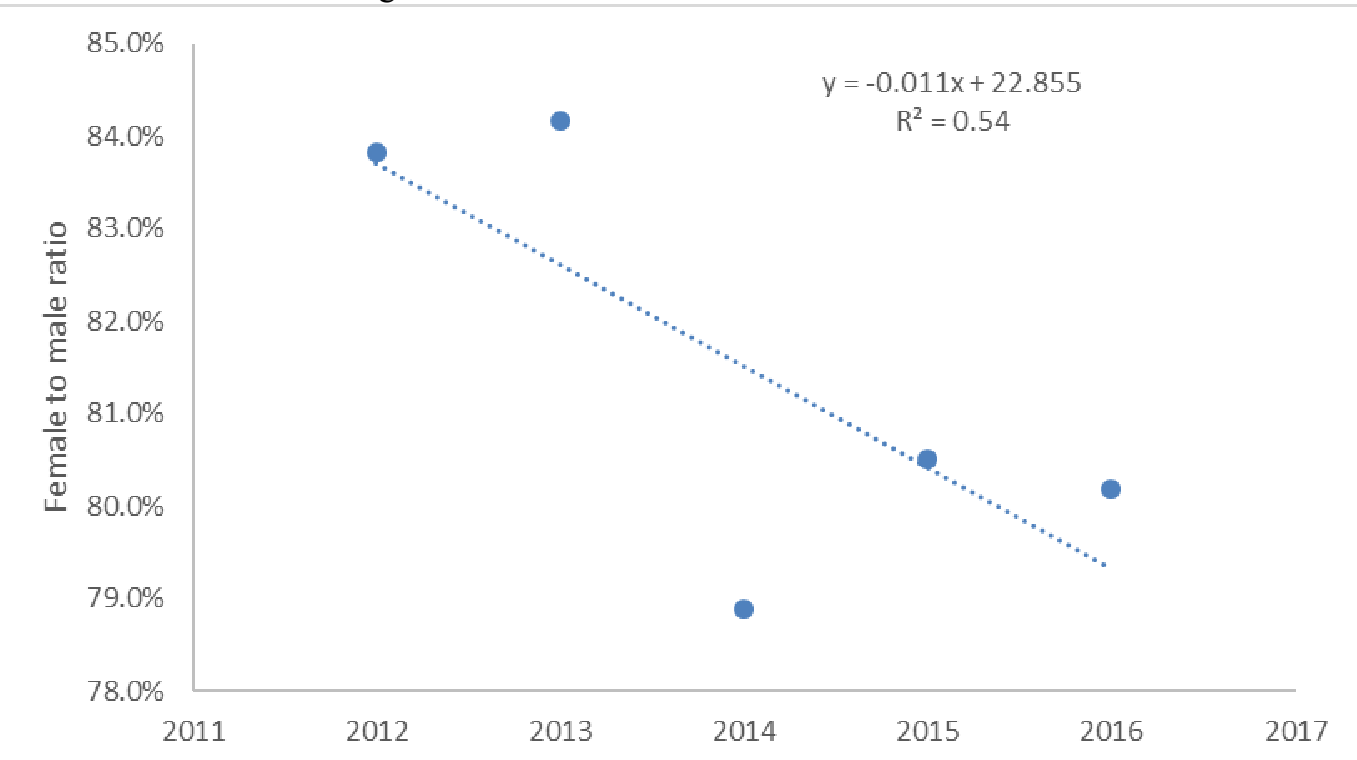

Figure 1: STEM and Non-STEM Male and Female Student Ratio at Admission for the Academic Year 20122016 
Figure 2 shows the female to male ratio. Overall this ratio has increased gradually over the years though slowly.

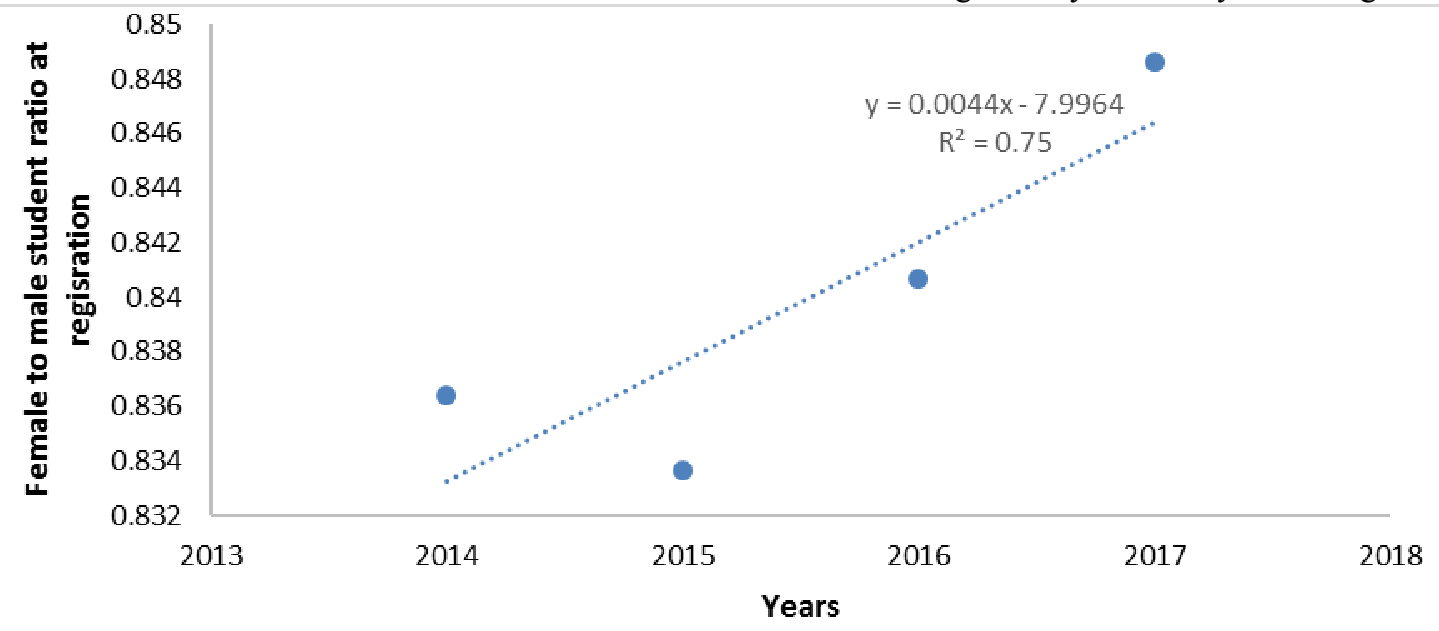

Figure 2: Female to Male Ratio at Registration

The student female to male ratio 2013/2014 drop is associated with the strike which hit the University at the beginning of the academic year causing a decrease in the relative increment of female students $(24.4 \%)$ compared to the male students $(32.9 \%)$. It is worthwhile to note that the female student's population was smaller $(3,535)$ compared to that of the male $(4,199)$ in the previous year.

\subsubsection{Undergraduate STEM and Non-STEM Graduation Trends at KyU 2014-2017}

Figure 3 shows that there is an increase over time in students' graduation from the Non-STEM fields with $\mathrm{R}^{2}=0.33$ for the undergraduate programmes $(\mathrm{P}<0.05)$. Decline overtime in STEM fields is evident as depicted by the coefficient of determination of 0.91 and the probability of rejection of the null hypothesis $(\mathrm{P}<0.05)$. Meaning that about $91 \%$ of the data is explained by the observed trend.

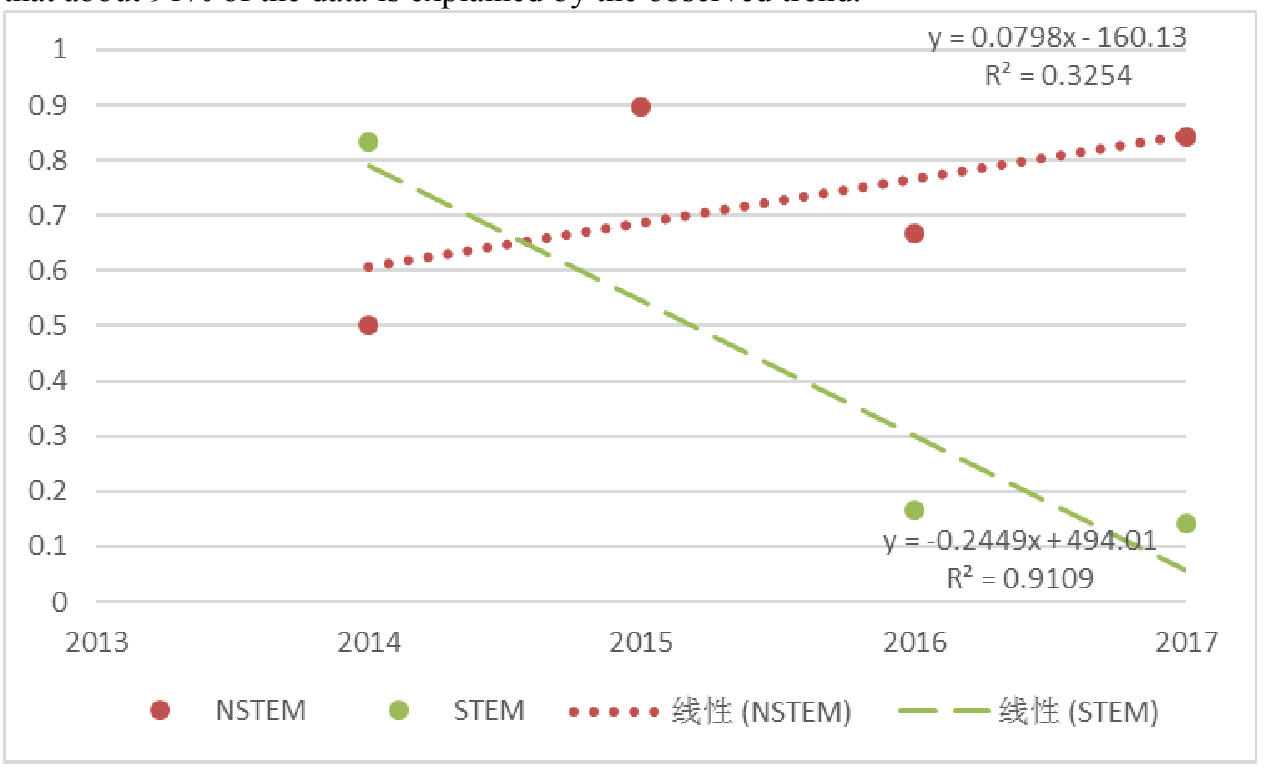

Figure 3: Undergraduate STEM and Non-STEM Graduation Trends at KyU 2014-2017

\section{Source: Kyambogo University Graduation Booklets 2014-2017}

3.1.4 STEM Graduation Trends per Faculty at Kyambogo University 2014-2017

Figure 4 shows that graduating Master Students were significantly declining overtime in the ratio of female over male students with $\mathrm{R}^{2}=0.91$. Post graduate diplomata has had a quadratic trend. First declining, and later on increased over time with a coefficient of determination $\left(\mathrm{R}^{2}\right)$ equal to 0.86 . Faculty of Engineering has slightly increased over time $\left(\mathrm{R}^{2}=0.50\right)$, and for Faculty of Science, the ratio declined slightly over time with $\left(\mathrm{R}^{2}=0.52\right)$. 


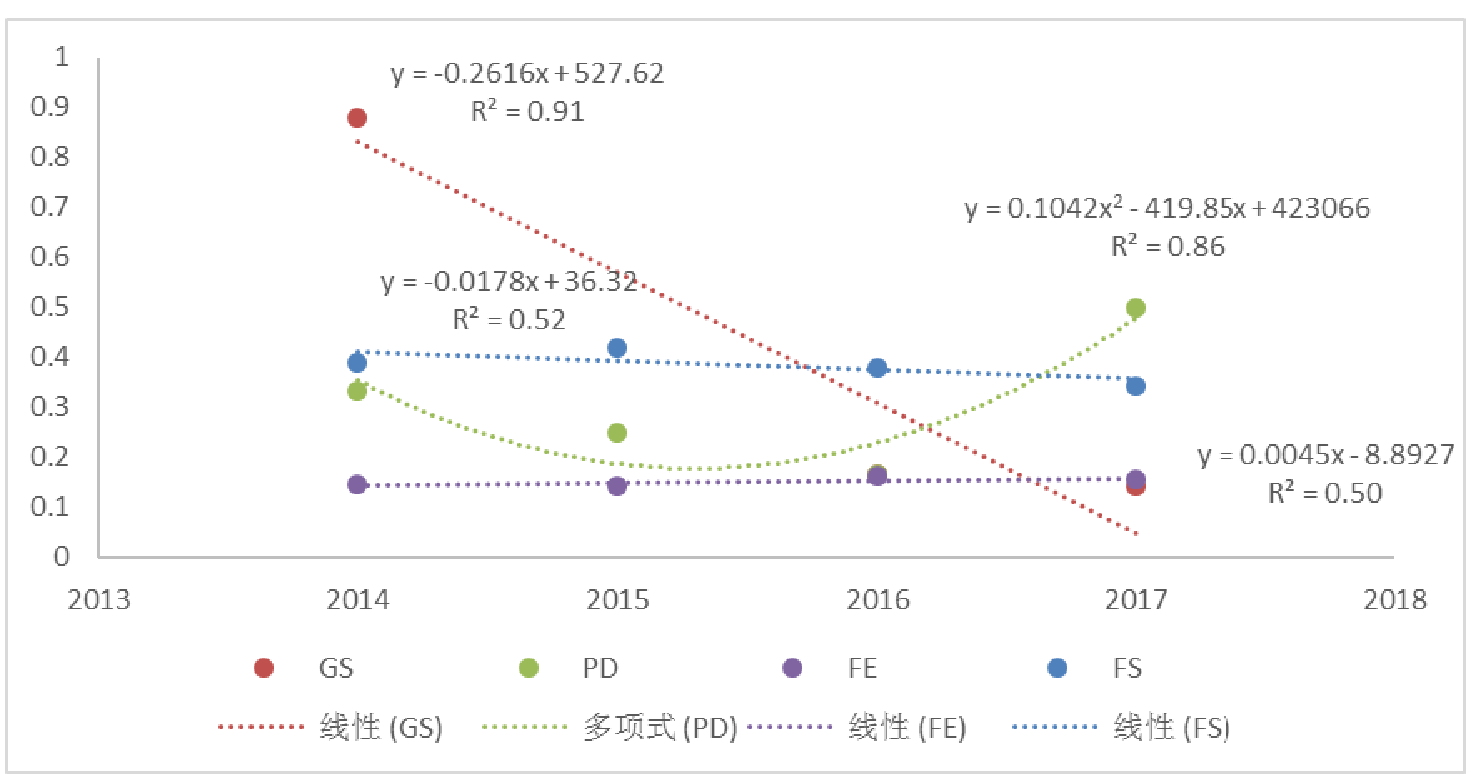

Figure 4: Graduation Trends of STEM per Faculty at KyU 2014-2017

Source: Kyambogo University Graduation Booklets 2014-2017

\subsubsection{Status of female to male ratio in student leadership positions}

The female to male ratio has been fluctuating over time for Cabinet, School of Management and Entrepreneurship, Chairpersons, Select committees of chair persons, Faculty of Arts and Social Sciences, and representatives of halls of residence (Figure 5). For select committee chairpersons and representatives of halls of residence, the female to male ratio had a peak 2013 and 2015, respectively, before declining for the rest of the leadership years. School of Management and Entrepreneurship also registered a peak in 2013 before declining over time for the rest of the year. The chairperson and the Arts and social science positions remained dominated by male students for the last five years and registered for an increase in the last year (2018). Even for leadership roles, male is still dominating the committee. Generally, the male to female ratio for student leadership positions was below 0.6. Meaning the number of males in the leadership position was almost double the number of females in those positions. There is therefore a need for leadership capacity building for female students.
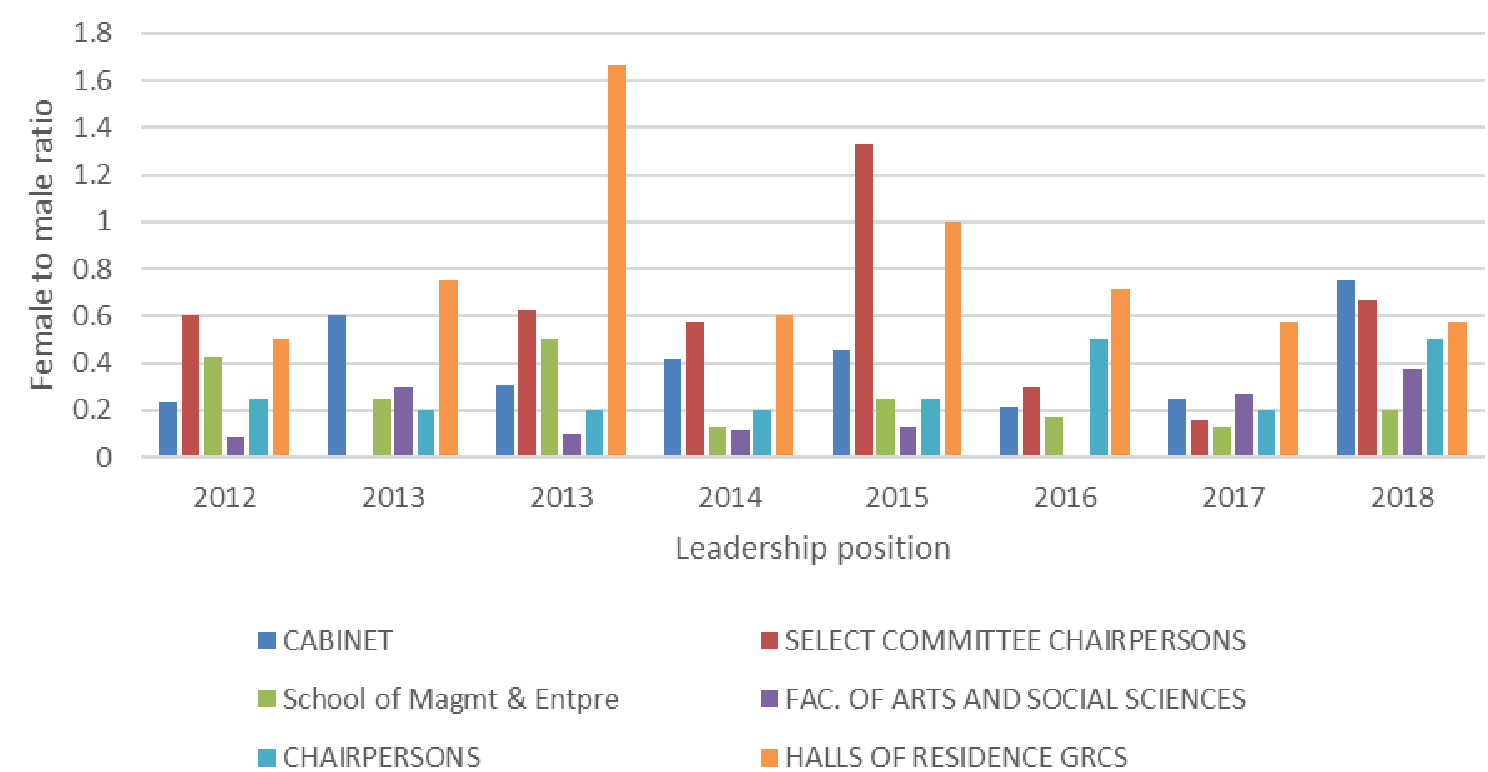

\section{- SELECT COMMTTEE CHAIRPERSONS \\ FAC. OF ARTS AND SOCIAL SCIENCES \\ HALLS OF RESIDENCE GRCS}

Figure 5: Female to Male Student ratio in Leadership Positions for the Period (2012-2018)

Apart from the Vice President position, where affirmative action was instituted, where when a male wins the President position automatically, then the female occupies the Vice Presidency position, the female to male ratio in student leadership positions is generally low for Faculty of Vocational Studies, Engineering, Science, Education Special Needs and Rehabilitation (Figure 6). 


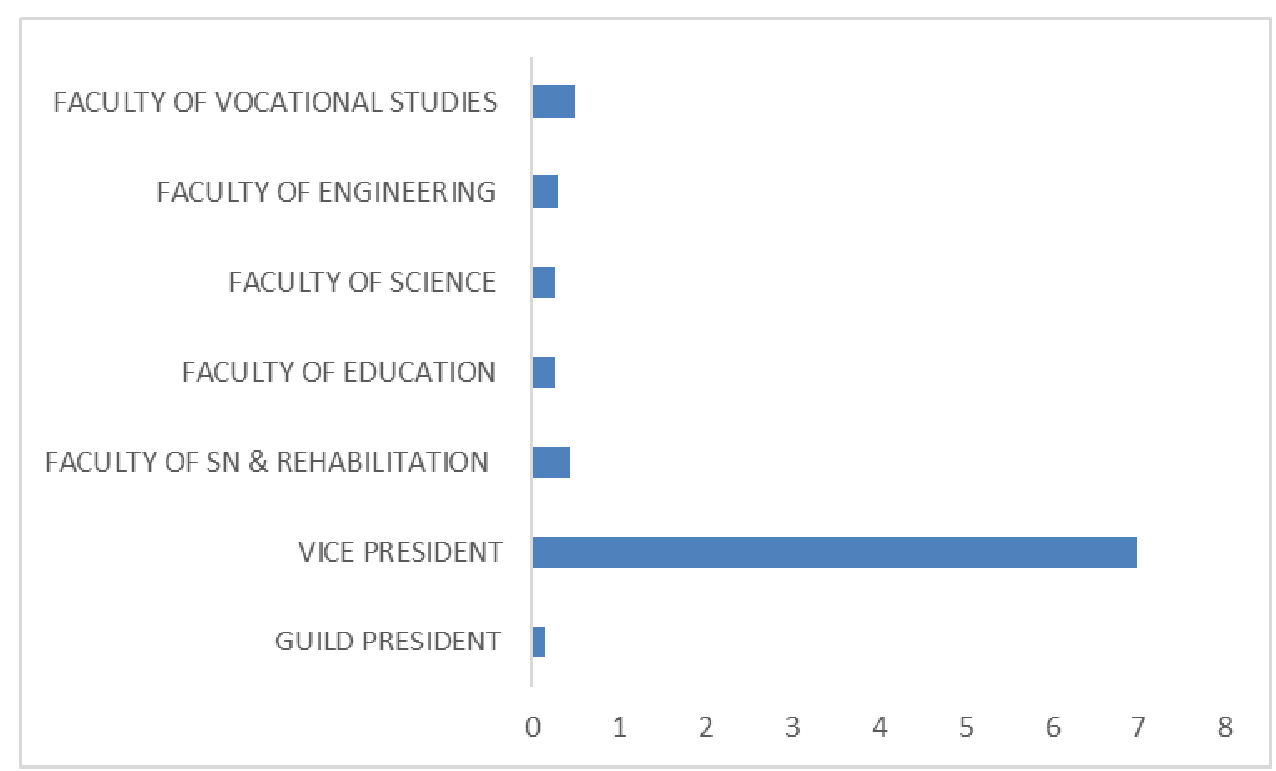

Figure 6: Female to Male Student Ratio in Leadership Positions (2012-2018)

\subsection{Female staff in leadership}

The ratio of female to male in the leadership position (Dean/Head of Department) is shown in Figure 7. Female to male ratio was relatively higher than 0.5 for in the faculty of arts and social sciences, School of management and entrepreneurship, faculty of vocational studies and faculty of sciences, For Non-STEM heads of departments, the ratio of female to male ranged from 0.33 to 1 . For STEM, it was either 0 or 0.75 . There is a need for capacity building in leadership for Faculty, Deans, and Heads of Departments, respectively, to attract female staff and graduates to compete for leadership positions (Figure 8).

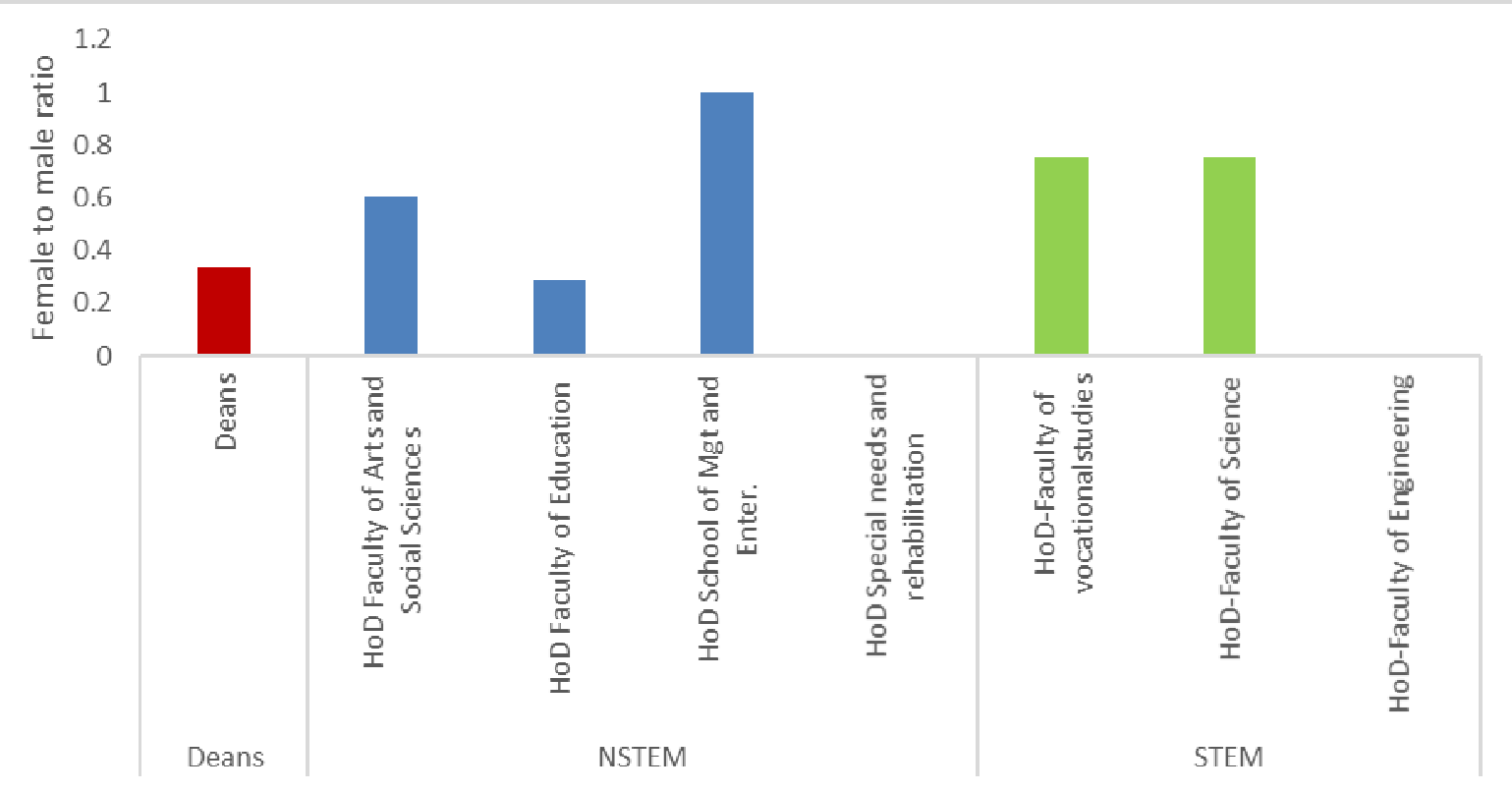

Figure 7 Female to Male ratio for Deans and Heads of Departments for Non-STEM and STEM Disciplines 


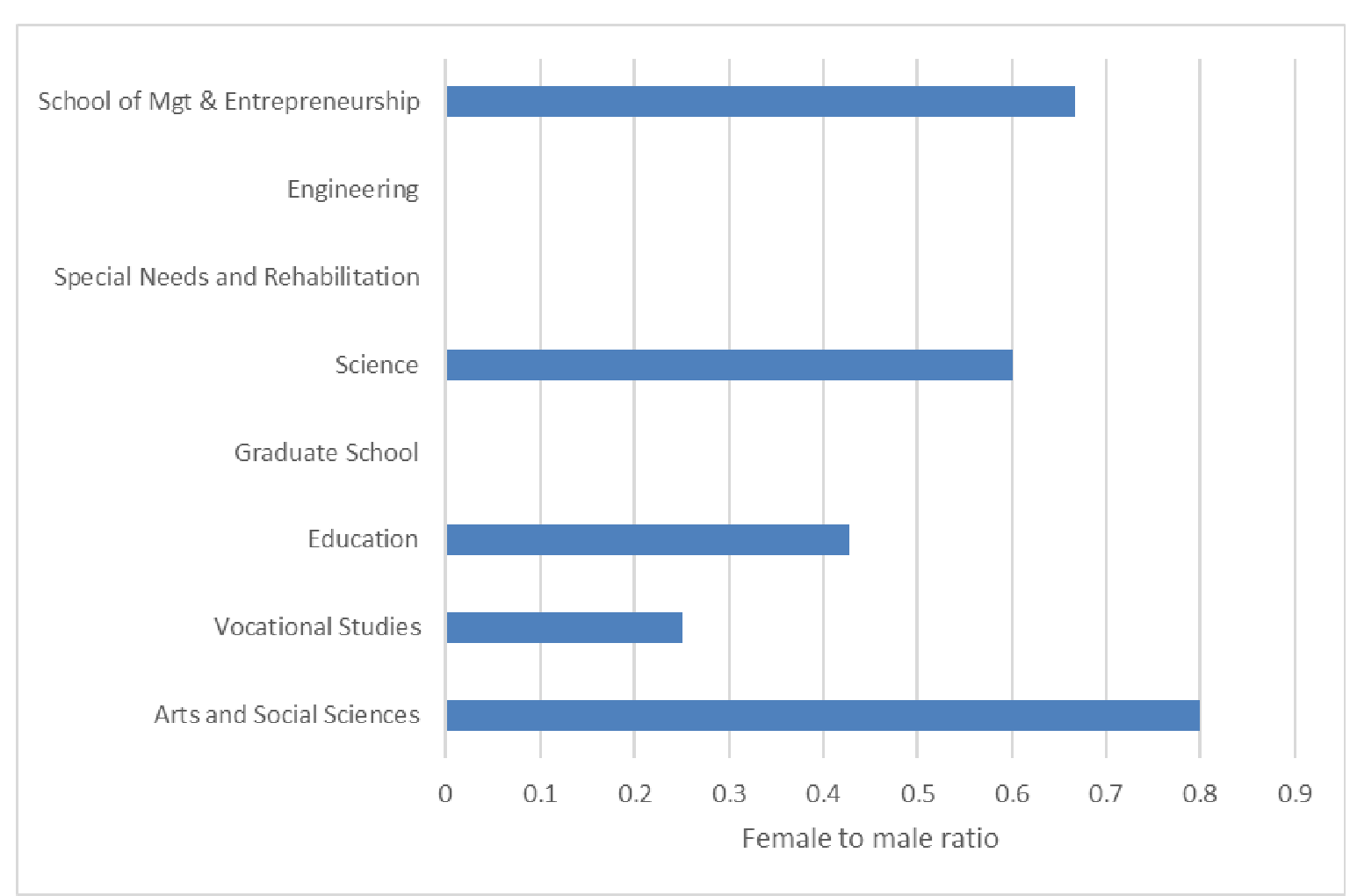

Figure 8: Female staff in a leadership positions at KYU

Source: Human Resource Records as of July, 2018

3.2 Strategies and policies for narrowing the gender gap for female students and academic staff offering STEM at KyU

\subsubsection{Human Resource}

Assessment of the Human Resource records of Kyambogo University (KyU) (2014) reveals an aggregate machinery (policies, rules, procedures, systems, organizational structures, personnel, etc.). For example, recruitment, appointment, promotion, and accrued salaries and allowances were based on merit and genderneutral criteria. The criteria do not take into consideration the different implications of such policies on women and men. In most cases, female academic staff are inadvertently disadvantaged compared to men (Human Resource Records of Kyambogo University, 2014). There is a need for instituting affirmative action in the recruitment, appointment, and promotion processes to enable female academic staff, for example, compete favorably with males especially in research and leadership positions. The University should move away from the weighted promotion criteria to aggregate performance in terms of publication, supervision, and community engagement of an academic staff. Equally important are the mechanisms for promoting female academic staff and their visibility in STEM disciplines. The need to ensure transparent and affirmative action criteria in the recruitment of female staff in STEM is important. For example, if the staffing structure, says in the engineering department requires 200 staff, at least 90 of its staff should be females. Once female staff have been recruited, there is a need for mentorship, coaching and networking programmes, especially for women who tend to have less access than men to networks and are often less visible than men in their work places.

\subsubsection{Strategic interventions for increasing female students at Kyambogo University affirmative action}

Kyambogo University like other public universities in Uganda, has benefited from the Government of Uganda's mandatory country wide gender equality policy (Affirmative Action). This was done by giving female high school graduates additional points (1.5points) to increase their chances of either gaining entry into the university or joining other professional courses. This has increased the overall growth in the number of female undergraduate students in various programs within the public universities in Uganda. This policy is also important as it supports a pool of educated females to enter the Public Service and other professions. As the Public Service is expected to be merit-based, equal access to higher education and affirmative action are important long-term requirements. At Kyambogo University, the Business and Social Sciences departments among other non-stem departments have in the academic year 2015-2018 registered more female students compared to the other STEM programs. The other strategic intervention that has contributed to the female increase in numbers at University is the introduction of the private scheme and the development of new degree programs. In the same year (2015-2018), the science-based programmes have received fewer students with 
limited numbers of female students compared to Non-STEM programmes.

\subsubsection{Funding of University Programmes}

Higher education in Uganda was originally free, covering tuition and living allowances until the introduction of the student private sponsorship scheme in the academic year 1991-1992. This was due to the growth of student numbers the Government of Uganda (GoU) could no longer afford to pay tuition and personal needs for all students that qualified to join tertiary/ higher institutions. The GoU has overtime offered bursaries to highly qualifying students at higher institutions, but with the growth in student numbers due to Universal Primary Education (UPE) and Universal Secondary Education (USE), support from the Government, many qualifying students miss the opportunity for government scholarships. There are structural reasons. For example, the sponsorship of students is based on the scores from highly well-performing schools, especially in urban areas, which has discriminated students from disadvantaged regions or backgrounds.

The review of sources of funding University students was conducted on a total of 24,263 registered students for the academic year 2017/2018. Funding was categorized as private, government, State House, and biological sponsorship schemes. The government of the Republic of Uganda sponsored highly academic talented male and female students $(2,469$ students) from high school joining the University. This scholarship was not limited to STEM fields or gender, rather cuts across all academic programs. Majority of the students $(21,781)$ were privately sponsored. This means that the parents of the students have to pay tuition, functional fees and cater for other maintenance needs of the student while few students (6) were sponsored by the state house or on a biological scheme (7 students) (e.g. when a parent of the student is a member of staff of $\mathrm{KyU}$, the scheme covers tuition and functional fees alone). It is important to note that the government scholarship is structured on a merit and quotas basis. For example, if the programme is not in the University quota, then the students of that programme will not be sponsored by government.

Another intervention by the government of Uganda was the establishment of a competitive student's study loan scheme for STEM and Non-STEM fields of study. The total Loan benefits 1,100 Students to pursue Science related programs in both Public and Private Universities (Chartered universities)

The loan covers tuition, research, and functional fees. The availability of funds to students was dependent on the loan envelop, family, school, and regional background.

Academic staff at Kyambogo University have benefited from various sources of funding to pursue Master's and Phds programs. This contributed to the increased numbers of staff qualifying with PhDs and Masters at the University. However, this has not been commensurate with promotion upon completion of studies due to irregularities in the Human Resource Manual. Another challenge was to ascertain the completion ratios of male to female staff due to the lack of sex-disaggregated statistics, which has limited the understanding, tracking patterns and completion trends of staff.

\section{Discussion}

The analysis was conducted at Kyambogo University, Uganda-East Africa, as a sample case study. The purpose of the study was twofold 1) determine the status and trend of female academic staff and student to male ratio and 2) identified practical strategies and policies for narrowing the gender gap among student offering and staff teaching STEM disciplines at Kyambogo University.

The analysis clearly shows evidence of male dominance in academic staffing in STEM and Non-STEM fields of study, and in academic leadership positions. However, there has been an increment in female student enrolment. These findings collaborate with those of (Grubbs \& Grubbs 2014) that women academics are an underrepresented part of many science faculties at many colleges and universities in the United States. (Sheltzer \& Smith 2014) indicated that the recruitment of women in physics and engineering remains stagnant. Some of the KyU policies reviewed indicating policy statements on promoting equity and equality provisions in the KyU Gender Policy and Human Resource Manual. Recruitment or promotion of academic staff is done on merit regardless of being male or female. There was a lack of deliberate institutional gender-responsive affirmative action strategies to increase women representation in academia and in leadership positions.

In a study on the goal congruity model of role entry, engagement, and exit: understanding communal goal processes in STEM gender gaps (Diekman 2017) indicated women chaired departments in only $2.7 \%$ of engineering, $5.9 \%$ of math or physical science, and $12.7 \%$ of life science departments. In contrast, women chaired in $23.4 \%$ and $31.5 \%$ of business and humanities departments, respectively. This means that gender differences in teaching and in enhancing the image of science and technological careers in universities persist. The lack of clear incentives or mandates to hire or promote female academics at levels that better reflect the gender makeup of their student body means that women will extinct from the academic 'pipeline'. Lack of female role models and mentoring programs for females could have been contributed to the few numbers of female university academics in the fields of science, technology, engineering, and mathematics (Tacsir et al., 2014). Yet Role modeling and mentoring programs encourage women in their career aspirations. Women gain self-confidence network with colleagues in similar situations and acquire a deeper understanding of university 
and research organizations and structures (Tacsir et al., 2014). Where there was a persistent decline of students graduating at the postgraduate level, it calls for an immediate inquiry. Both male and female students may no longer want to be bothered with reading or academic staff are not motivated to supervise student's projects, or there are limited enrolment, retention, and completion guidelines.

\section{Limitation of the study}

The study identified a range of gender gaps among male and female students and staff in teaching and learning, and leadership positions for both STEM and non-STEM disciplines. However, the status of study cannot be generalized to other core functions of the university or other universities in Uganda. Additionally, the study relied more on desk review and could not address the social- economic and political aspects that question the existing gender gaps among university male and female students and staff.

\section{Conclusion}

Results shows evidence of male dominance in academic staffing in STEM and Non-STEM fields of study, and in academic leadership positions at KyU. These results should not be generalized to other core functions of KyU or other universities in Uganda and beyond. Instead, the results should be used as a springboard and form part of the policy agenda in STEM departments towards increasing numbers of female science academics and students and increasing leadership positions at universities in the country. This growth can help further expand opportunities for future generations of female science academics and leaders in universities in Uganda and beyond. $\mathrm{KyU}$ is mandated with teacher education in the country and hence the need to implement gender responsive programmes that enhance entry, retention, and participation in leadership positions for both female students in STEM fields. This is critical for both male and female academics and nonacademic in contributing towards economic and scientific growth and for individual professional development.

\section{Recommended Key Policy Interventions}

- The university should explore the ways at first instituting a Female Undergraduate Scholarship Program (FUSP) to target female students offering STEM fields. Second, establish a six weeks female pre-entry course in advanced and applied mathematics, biology, physics, and chemistry before entering the university. The aims of the two strategies would create a pool of female students from secondary schools to join university and pursue STEM programs. On passing pre-entry exams, qualified students would be encouraged to participate in the regular enrolment process of admission in STEM related programs. This can also start a discussion on policy review, formulation, and implementation of female admissions in universities.

- $\quad$ On graduation, the best performers with an outstanding Grade Point Average (GPA) (e.g., from 3.8 onwards) would be retained as part of the academic staff in the STEM department s. This would inspire many girls to work harder and view successful women who would become role models and mentors to female students offering STEM within the University and beyond.

- There is a need for out-of-University programs. For example, KyU STEM departmental students can partner with primary and secondary schools with the purpose of encouraging their peers to join university. This could be done through STEM students organizing exhibitions, celebrations, and television and radio talk shows and inviting primary and secondary schools to participate in such activities with the aim of attracting both male and female students to join university.

- Kyambogo University, whose mandate is in teacher education, should come up with an enhanced curriculum. Primary Teachers Colleges (PTCs) and National Teachers Colleges (NTCs) need to be encouraged to establish crop and animal farms, technical workshops for the production of handmade equipment and repair of household appliances. Emphasis should be put on the interrelationship of science, mathematics, technical, and vocational training. In science, the conditions necessary for plant growth should be demonstrated and studied, as well as farm management, appropriate tools, etc. should be introduced. Relevant mathematical concepts like length and area, calculation of yield, profit and loss, etc. and making of hand grain shelters, repairing of tools, etc. Given the high dropout rates in Uganda, learners who would leave primary school with such educational experiences would have potential successful careers like poultry keeping, brick-making, carpentry, and others.

- Primary teachers should give an opportunity to pupils to explore preferred STEM career choices. This will prevent the subject forced choice system that tends to widen the gap between girls' and boys' attitudes towards STEM. The University through its outreach programs (PTCs and NTCs) must demonstrate and build positive aspects about the long-term benefits towards STEM fields.

- Kyambogo University outreach programs like PTCs and NTCs should be supported to maintain good STEM grades especially by girls in their early years. This can be achieved through promotion of gender-responsive learning styles and interest in transmitting STEM knowledge. Therefore, to ease 
gender equity and equality in science, it is critical to identify programs that match girls' learning styles and provide learner-centered environments and materials at an early age. Kumar et al. (2017), asserts that when designing innovative STEM learning environments, there is a need for developing learning environments known as the "Learning Sciences."

- There is also a need for gender disaggregated data in STEM at national and subregional levels in East and Central Africa to help policy makers; program implementers make informed decisions on resolving gender disparities in STEM. This will close the continuous widening of the gap of females in STEM.

\section{Availability of data and materials}

The datasets used and/or analysed during this study are available from the corresponding author on reasonable request. Third - party includes the citations listed in the reference section.

\section{Conflicts of interest}

The authors declare that they have no competing interests Funding

This study has not yet received funding

\section{Acknowledgement}

This research study was made possible with the support of both academic and administrative staff of Kyambogo University that availed us with information.

\section{References}

Aina, I. O. (1998). "Women, culture and Society" in Amadu Sesay and Adetanwa Odebiyi (eds). Nigerian Women in Society and Development. Dokun Publishing House, Ibadan

Blackburn, H. (2017). The Status of Women in STEM in Higher Education: A Review of the Literature 20072017. Science \& Technology Libraries, 36(3), 235-273.

Blickenstaff, J. C. (2006). Teacher Leaders as Intern Supervisors: Lessons from an MSP Project. In Bulletin of the American Astronomical Society (Vol. 38, p. 895).

Chen, X. (2009). Students Who Study Science, Technology, Engineering, and Mathematics (STEM) in Postsecondary Education. Stats in Brief. NCES 2009-161. National Center for Education Statistics.

Crittenden, V. L., Crittenden, W. F., \& Ajjan, H. (2019). Empowering women micro-entrepreneurs in emerging economies: The role of information communications technology. Journal of Business Research, 98, 191203.

Diekman, A. B., Steinberg, M., Brown, E. R., Belanger, A. L., \& Clark, E. K. (2017). A goal congruity model of role entry, engagement, and exit: Understanding communal goal processes in STEM gender gaps. Personality and Social Psychology Review, 21(2), 142-175

Government of Uganda. (2011). Skilling Uganda BTVET Strategic Plan 2011-2020, Ministry of Education and Sports.

Grubbs, K. C., \& Grubbs, S. J. (2016). Increasing Female Academics in Science in the United States: An Examination of Policies. International Journal of Gender, Science and Technology, 8(2), 279-299.

Hernández, J. (2016). El gaucho Martin Fierro (1872). In Letras hispánicas en la gran pantalla (pp. 69-89). Routledge.

Herrmann, S. D., Adelman, R. M., Bodford, J. E., Graudejus, O., Okun, M. A., \& Kwan, V. S. (2016). The effects of a female role model on academic performance and persistence of women in STEM courses. Basic and Applied Social Psychology, 38(5), 258-268.

Human Resource Records for Kyambogo University. (2014). Kampala, Uganda.

Hutton, D. M., \& Dixon, R. A. (2016). Technical and vocational education and training (TVET) and its integration into general education at the university level.

Jackson, P. T. (2016). The conduct of inquiry in international relations: philosophy of science and its implications for the study of world politics. Routledge.

Kumar, A., Singh, N., \& Ahuja, N. J. (2017). Learning styles based adaptive intelligent tutoring systems: Document analysis of articles published between 2001. and 2016. International Journal of Cognitive Research in Science, Engineering and Education, 5(2), 83.

Lone, S. W., Kayani, A. I., \& Kiran, S. (2019). Empowering Women through Education: A Cultural \& Global Issue for Sustainable Growth.

McLaughlin, T. H. (2017). Liberalism, education and schooling: essays by TH McLaughlin (Vol. 9). Andrews UK Limited.

Pailey, R. N. (2019). Women, Equality, and Citizenship in Contemporary Africa. In Oxford Research Encyclopedia of Politics.

Parpart, J. L., Flint, J. E., \& Luke, D. F. (1989). Women and development in Africa: comparative perspectives. 
University Press of America.

Riegle - Crumb, C., \& Moore, C. (2014). The gender gap in high school physics: Considering the context of local communities. Social Science Quarterly, 95(1), 253-268.

Sheltzer, J. M., \& Smith, J. C. (2014). Elite male faculty in the life sciences employ fewer women. Proceedings of the National Academy of Sciences, 111(28), 10107-10112.

Smith, E. (2010). Do we need more scientists? A long - term view of patterns of participation in UK undergraduate science programmes. Cambridge Journal of Education, 40(3), 281-298.

Swers, M. L. (2013). Women in the club: Gender and policy making in the Senate. University of Chicago Press.

Tacsir, E., Grazzi, M., \& Castillo, R. (2014). Women in Science and Technology: What Does the Literature Say? Inter-American Development Bank.

Tamale, S. (2008). The right to culture and the culture of rights: a critical perspective on women's sexual rights in Africa. Feminist Legal Studies, 16(1), 47-69.

Wang, M. T., \& Degol, J. L. (2017). Gender gap in science, technology, engineering, and mathematics (STEM): Current knowledge, implications for practice, policy, and future directions. Educational Psychology Review, 29(1), 119-140

Young, D. M., Rudman, L. A., Buettner, H. M., \& McLean, M. C. (2013). The influence of female role models on women's implicit science cognitions. Psychology of Women Quarterly, 37(3), 283-292. 